\title{
Spinal Adenosine A2a Receptor Activation Elicits Long- Lasting Phrenic Motor Facilitation
}

\author{
Francis J. Golder, Lavanya Ranganathan, Irawan Satriotomo, Michael Hoffman, Mary Rachael Lovett-Barr, \\ Jyoti J. Watters, Tracy L. Baker-Herman, and Gordon S. Mitchell \\ Department of Comparative Biosciences, University of Wisconsin, Madison, Wisconsin 53706
}

\begin{abstract}
Acute intermittent hypoxia elicits a form of spinal, brain-derived neurotrophic factor (BDNF)-dependent respiratory plasticity known as phrenic long-term facilitation. Ligands that activate $\mathrm{G}_{\mathrm{s}}$-protein-coupled receptors, such as the adenosine 2a receptor, mimic the effects of neurotrophins in vitro by transactivating their high-affinity receptor tyrosine kinases, the Trk receptors. Thus, we hypothesized that A2a receptor agonists would elicit phrenic long-term facilitation by mimicking the effects of BDNF on TrkB receptors. Here we demonstrate that spinal A2a receptor agonists transactivate TrkB receptors in the rat cervical spinal cord near phrenic motoneurons, thus inducing long-lasting (hours) phrenic motor facilitation. A2a receptor activation increased phosphorylation and new synthesis of an immature TrkB protein, induced TrkB signaling through Akt, and strengthened synaptic pathways to phrenic motoneurons. RNA interference targeting TrkB mRNA demonstrated that new TrkB protein synthesis is necessary for A2a-induced phrenic motor facilitation. A2a receptor activation also increased breathing in unanesthetized rats, and improved breathing in rats with cervical spinal injuries. Thus, small, highly permeable drugs (such as adenosine receptor agonists) that transactivate TrkB receptors may provide an effective therapeutic strategy in the treatment of patients with ventilatory control disorders, such as obstructive sleep apnea, or respiratory insufficiency after spinal injury or during neurodegenerative diseases.
\end{abstract}

Key words: plasticity; breathing; neurotrophin; adenosine; transactivation; phrenic

\section{Introduction}

The respiratory neural network must accommodate the everchanging demands on breathing experienced during an individual's lifetime, including adjustments for physical activity, aging, pregnancy, and the onset of disease. Transient adjustments to respiratory motor output are achieved through a variety of feedforward and sensory feedback mechanisms. However, with repeated or chronic perturbations, the respiratory control system exhibits functional plasticity, a change in system performance based on previous experience (Mitchell and Johnson, 2003). Understanding endogenous mechanisms of respiratory plasticity may enable the development of novel therapeutic strategies aimed at improving respiratory function in ventilatory control disorders, such as respiratory insufficiency during spinal cord injury.

Long-term changes in respiratory motoneuron function can

\footnotetext{
Received Aug. 6, 2007; revised Jan. 13, 2008; accepted Jan. 14, 2008.

This work was supported by National Institutes of Health Grants HL69064, HL80209, Training Grant HL07654 (M.H.), and the Francis Families Foundation (T.L.B.-H.). We gratefully acknowledge the generous gift of phosphoTrkB antibody from M. V. Chao and R. Rajagopal (School of Medicine, New York University, New York, NY) and pTrk antibody from R. Segal (School of Medicine, Harvard University, Cambridge, MA). We also gratefully acknowledge important contributions to these studies by B. Hodgeman, J. Dahlberg, D. Harrigan, S. Mahamed, and V. Brautigam. Some control rat experiments were completed at the University of Pennsylvania.

Correspondence should be addressed to Prof. Gordon S. Mitchell, Department of Comparative Biosciences, University of Wisconsin, 2015 Linden Drive, Madison, WI 53706. E-mail: mitchell@svm.vetmed.wisc.edu.

F. J. Golder's present address: Department of Clinical Studies-Philadelphia, University of Pennsylvania, Philadelphia, PA 19104.

L. Ranganathan's present address: GenTel Biosciences, Fitchburg, WI 53711.

D0I:10.1523/JNEUROSCI.3570-07.2008

Copyright $\odot 2008$ Society for Neuroscience $\quad$ 0270-6474/08/282033-10\$15.00/0
}

occur via plasticity of their synaptic inputs (Mitchell and Johnson, 2003; Golder and Mitchell, 2005). Several models of respiratory synaptic plasticity are induced by neuromodulators such as serotonin and/or norepinephrine versus synaptic activity per se (Feldman et al., 2003; Bocchiaro and Feldman, 2004; Neverova et al., 2007). Downstream signaling mechanisms often involve the neurotrophin brain-derived neurotrophic factor (BDNF) and its high-affinity receptor tyrosine kinase, TrkB (Carter et al., 2002; Baker-Herman et al., 2004; Bramham and Messaoudi, 2005). For example, acute intermittent hypoxia elicits a long-lasting enhancement of phrenic motor activity known as phrenic longterm facilitation (pLTF) (Mitchell et al., 2001). pLTF requires new protein synthesis, most notably new BDNF synthesis (BakerHerman et al., 2004). BDNF may strengthen excitatory glutamatergic synapses from brainstem respiratory neurons onto phrenic motoneurons, thus enhancing inspiratory motoneuron activity and increasing diaphragm contractions (Feldman et al., 2003). Although intermittent hypoxia has the potential to match motor function with repetitive changes in demand, it is a nonspecific stimulus that may affect many physiological functions and induce pathology (Bass et al., 2004). Thus, models of phrenic motor plasticity that do not require hypoxia are more likely candidates for the development of new therapeutic options to treat respiratory insufficiencies.

BDNF applied to the spinal cord is sufficient to induce phrenic motor facilitation (Baker-Herman et al., 2004). However, CNS administration of proteins is riddled with problems associated with delivery across the blood-brain barrier, penetration to the 
relevant neural site, and the unintended activation of immune responses against a foreign protein. An alternative approach would be the use of small, highly permeable molecules with properties that mimic the effects of BDNF on respiratory motor output. Adenosine 2 a receptor (A2a) activation mimics neurotrophins by transactivating Trk receptors without their neurotrophin ligands in PC12 cells (Lee and Chao, 2001; Lee et al., 2002; Rajagopal et al., 2004). Thus, we hypothesized that spinal A2a receptor activation would transactivate TrkB receptors and mimic the effects of BDNF on phrenic motor output. Here we report that spinal A2a receptor activation elicits phrenic motor facilitation in rats by increasing phosphorylation and intracellular signaling of an immature TrkB receptor isoform near phrenic motoneurons. Furthermore, we report that the capacity to induce phrenic motor facilitation can be harnessed by systemic administration of the A2a receptor agonist, thereby improving breathing in rats with respiratory insufficiency resulting from cervical spinal injury.

\section{Materials and Methods}

Animals and experimental groups. All experiments were conducted on adult (3-6 months of age) male Sprague Dawley rats (308-364 g; Harlan colony 217; Harlan, Indianapolis, IN). The initial experiment was designed to investigate phrenic motor facilitation after spinal A2a receptor activation in anesthetized rats. The second series of experiments explored the relationship between the magnitude of A2a-induced phrenic motor facilitation and strengthening of synaptic pathways onto phrenic motoneurons. In a third series, $\mathrm{C} 4$ ventral horn TrkB isoforms were examined with Western analyses for A2a-induced TrkB levels and phosphorylation state, as well as phosphorylation state in its downstream signaling molecules (ERKs $1 / 2$ and protein kinase B). Immunohistochemistry was performed to confirm and localize changes in TrkB protein and phosphorylation within cells of the $\mathrm{C} 4$ ventral gray matter. Fourth, RNA interference (RNAi) targeting TrkB and BDNF mRNA was used to inhibit new TrkB and BDNF protein synthesis, thus enabling a test of the hypothesis that new TrkB, but not BDNF, protein synthesis is necessary for A2a-induced phrenic motor facilitation. Finally, the effect of A2a receptor activation on ventilatory function was examined in unanesthetized, freely behaving uninjured rats and in $\mathrm{C} 2$ spinally injured rats with decreased tidal volume. All experimental procedures were approved by the Institutional Animal Care and Use Committee of the School of Veterinary Medicine at the University of Wisconsin, Madison.

Measurement of respiratory motor output. To determine the effects of spinal A2a receptor activation on phrenic motor activity, integrated phrenic amplitude was recorded in anesthetized rats before and after intrathecal drug administration. Anesthesia was induced with isoflurane. Fluid $\left(4 \mathrm{ml} \cdot \mathrm{kg}^{-1} \cdot \mathrm{h}^{-1}\right.$, i.v.; 50:50 mixture of lactated Ringer's and 6\% hetastarch) was administered throughout the experiment. The trachea was cannulated, and rats were mechanically ventilated (rodent respirator model 683; Harvard Apparatus, South Natick, MA). Both cervical vagi were transected to prevent entrainment of phrenic activity with the ventilator. A femoral arterial catheter enabled arterial blood pressure monitoring (model P122; Grass Telefactor, West Warrick, RI) and sampling of arterial blood for $\mathrm{pH}$ and blood gas analysis (ABL-500; Radiometer, Copenhagen, Denmark). End-tidal $\mathrm{pCO}_{2}$ was measured continuously (Capnoguard; Novametrix Medical Systems, Wallingford, CT). The C2 spinal segment was exposed for intrathecal drug administration and positioning a stimulating electrode in the lateromedial funiculus. To enable intrathecal drug injections, a cannula attached to a Hamilton syringe and filled with the specified drug or vehicle solution was advanced through a $\mathrm{C} 2$ durotomy until the tip of cannula rested over the $\mathrm{C} 4$ spinal segment.

After surgical preparation, rats were converted to urethane anesthesia $\left(1.8 \mathrm{~g} \cdot \mathrm{kg}^{-1}\right.$, i.v. $)$ while isoflurane was discontinued, and then neuromuscularly paralyzed (pancuronium bromide, $1 \mathrm{mg} \cdot \mathrm{kg}^{-1}$, i.v.). Phrenic nerves were isolated, and motor activity was recorded continuously with bipolar silver electrodes, amplified, rectified, moving averaged, digitized, recorded, and analyzed as previously described (Golder and Mitchell,
2005). At least $1 \mathrm{~h}$ elapsed after conversion to urethane anesthesia before protocols began.

Baseline nerve activity was established at $\sim 2-3 \mathrm{mmHg}$ above the apneic threshold (Golder and Mitchell, 2005). Peak integrated phrenic nerve burst amplitude was recorded for $30 \mathrm{~min}$ at baseline conditions and for $120 \mathrm{~min}$ after intrathecal drug administration. Arterial blood samples were collected during baseline conditions and 30, 60, 90, and 120 min after intrathecal drug administration. Peak moving-averaged phrenic neurogram burst amplitude and burst frequency ("fictive" respiratory depth and rate) were measured off-line over a $20 \mathrm{~s}$ period immediately before blood samples. Arterial $\mathrm{pCO}_{2}\left(\mathrm{PaCO}_{2}\right)$ was controlled by adjusting the level of inspired $\mathrm{CO}_{2}$ or by making ventilator adjustments; blood pressure was maintained by varying the fluid infusion rate. Animals were included in the final analysis only if $\mathrm{PaO}_{2}$ during the entire experiment remained $>150 \mathrm{mmHg}$, and $\mathrm{PaCO}_{2}$ was within $1 \mathrm{mmHg}$ of the baseline value during postinjection measurement periods.

Drug administration. 2-p-(2-Carboxyethyl)phenethylamino-5' $-\mathrm{N}$ ethylcarboxamidoadenosine hydrochloride (CGS 21680; Sigma-Aldrich, St. Louis, MO) is a relatively specific A2a receptor agonist. CGS 21680 (50 $\mu \mathrm{M})$ was dissolved in DMSO and administered intrathecally over the C4 spinal segment $\left(2 \mu \mathrm{g} \cdot \mathrm{kg}^{-1}\right)$ or intraperitoneally $\left(100 \mu \mathrm{g} \cdot \mathrm{kg}^{-1}\right)$ to anesthetized (series 1-4) and (series 5) unanesthetized rats, respectively. The intrathecal dose of CGS 21680 was chosen based on preliminary dose-response studies, using the minimal dose required to achieve consistent phrenic motor facilitation. The intraperitoneal dose was chosen as the minimal dose required for phrenic motor facilitation in anesthetized rats without significant effects on arterial blood pressure. In some rats, MSX-3 (130 ng $\cdot \mathrm{kg}^{-1} ; 10 \mu \mathrm{M}$ dissolved in DMSO; Sigma-Aldrich), a specific A2a receptor antagonist, was administered intrathecally $30 \mathrm{~min}$ before CGS 21680 injection to confirm that the effects of CGS 21680 were caused by $\mathrm{C} 4$ spinal $\mathrm{A} 2 \mathrm{a}$ a receptor activation. The dose of A2a antagonist was chosen based on preliminary dose-response studies. K252a, a tyrosine kinase inhibitor, prevents $\mathrm{TrkB}$ receptor phosphorylation in response to neurotrophin binding. K252a $\left(1.75 \mu \mathrm{g} \cdot \mathrm{kg}^{-1} ; 150 \mu \mathrm{M}\right.$ dissolved in DMSO; Sigma-Aldrich) was administered intrathecally to some rats 30 min before intrathecal CGS 21680 injection to determine whether A2a-induced changes in phrenic motor output required C4 spinal TrkB phosphorylation. The dose of K252a required to block TrkB phosphorylation was determined from preliminary studies in which the minimal dose of K252a needed to block the effects of BDNF on phrenic motor output (Baker-Herman et al., 2004) was identified. Emetine is a translation inhibitor that blocks new protein synthesis. In some rats, emetine was administered intrathecally $30 \mathrm{~min}$ before CGS 21680 to investigate the role of new protein synthesis in the effects of CGS 21680 on phrenic motor output. The dose of emetine $\left(1 \mu \mathrm{g} \cdot \mathrm{kg}^{-1} ; 75 \mu \mathrm{M}\right.$ dissolved in DMSO; Sigma-Aldrich) was chosen from a previous study (BakerHerman et al., 2004).

Phrenic evoked compound action potentials. To determine the effects of spinal A2a receptor activation on the strength of short-latency synaptic pathways to phrenic motoneurons (presumptive monosynaptic premotor inputs), we recorded phrenic evoked potentials before and after intrathecal drug administration. Details of the phrenic evoked potential recording technique have been published previously (Fuller et al., 2003, 2006). Rats were hyperventilated (end-tidal $\mathrm{PCO}_{2}, 27-33 \mathrm{mmHg}$ ) to prevent spontaneous phrenic motor activity, thereby isolating phrenic synaptic inputs from central respiratory drive. A monopolar tungsten electrode was positioned in the ventrolateral C2 spinal funiculus $(2.0-2.2$ $\mathrm{mm}$ below the dorsal root entry zone). Electrode position was selected by maximizing the amplitude of a short-latency $(<0.8 \mathrm{~ms})$ evoked potential in the phrenic nerve ipsilateral to the stimulating electrode. Preliminary experiments of stimulus-response relationships indicated a sigmoid response curve to increasing current pulses (20-1000 $\mu \mathrm{A}, 0.2 \mathrm{~ms}$ duration) using a stimulator (model S88; Grass Instruments, Quincy, MA) and stimulus isolation unit (model PSIU6E; Grass Instruments). Based on these experiments, four stimulating currents (threshold current and threshold $+100 \mu \mathrm{A}, 500 \mu \mathrm{A}$, and $1000 \mu \mathrm{A}$ ) were delivered to anesthetized rats before and after intrathecal drug administration. Phrenic potentials were digitized and analyzed with P-CLAMP software (Molecular Devices, Sunnyvale, CA). 
In vivo $R N A i$. Rats that received small interfering RNAs (siRNAs) were surgically prepared as described above. A pool of siRNAs targeting TrkB mRNA was used to determine the role of new synthesis of TrkB protein in A2a-induced phrenic motor facilitation. TrkB siRNAs were obtained as a pool of four $21 \mathrm{nt}$ duplexes (siGENOME, Dharmacon, Lafayette, CO; gene, NTRK2; GenBank accession number, NM 012731). We also used two separate siRNA sequences as internal negative controls: (1) an siRNA with at least four mismatches with all known human, mouse, and rat genes (siCONTROL NonTargeting siRNA \#2; Dharmacon) and (2) a pool of functional control siRNAs targeting BDNF. The sequences for the BDNF siRNA prevent new synthesis of C4 spinal BDNF and have been published in detail previously (Baker-Herman et al., 2004). siRNAs were reconstituted with siRNA Universal Buffer (Dharmacon; final concentration, $50 \mu \mathrm{M}$ ) and stored at $-20^{\circ} \mathrm{C}$. The minimal concentration of TrkB siRNA required to abolish $\mathrm{A} 2 \mathrm{a}$-induced phrenic motor facilitation (50 nM total RNA) was determined from preliminary dose-response studies. siRNAs ( $5 \mu \mathrm{l}$ of $500 \mathrm{~nm}$ solution) were combined with Oligofectamine ( 8 $\mu \mathrm{l}$; Invitrogen, Carlsbad, CA), a transfection reagent, and RNase-free water $(37 \mu \mathrm{l})$ and incubated at room temperature for $20 \mathrm{~min}$. The siRNAs were injected over the C4 spinal segment via an intrathecal catheter (two $10 \mu$ injections separated by $5 \mathrm{~min}$ ). Two hours were allowed before initiating the protocol with intrathecal CGS 21680.

Western analysis. The $\mathrm{C} 4$ spinal segment, which contains the majority of phrenic motoneurons, was removed at the end of electrophysiological experiments, snap-frozen on dry ice, and stored at $-80^{\circ} \mathrm{C}$ before homogenization. The spinal segment was mounted on a freezing microtome and the dorsal spinal cord shaved off until the area around the central canal was visible. Only data from ventral spinal cords are reported here. Tissue samples were homogenized in RIPA buffer $(200-400 \mu \mathrm{l})$ and centrifuged $\left(7000 \times g\right.$ at $4^{\circ} \mathrm{C}$ for $\left.10 \mathrm{~min}\right)$. The supernatant was collected and separated into aliquots. Total protein was quantified using the bicinchoninic acid method from a commercially available kit (Pierce Biotechnology, Rockford IL). Samples were combined with $6 \times$ SDS-PAGE sample buffer (100 mм Tris, 7.5 mм EDTA, 100 mм DTT, 6\% SDS, 30\% glycerol, and $1 \%$ bromophenol blue) and boiled for $4-5 \mathrm{~min}$, and $50 \mu \mathrm{g}$ of protein was loaded into each well. Proteins were separated by $8 \%$ SDS-PAGE gels and then transferred to Immobilon polyvinylidene difluoride membranes (Millipore, Bedford, MA). For pERK1/2 (1:2500; Cell Signaling Technology, Beverly, MA), ERK1/2 (1:2500; Cell Signaling Technology), pAkt (1:1000; Cell Signaling Technology), and Akt (1:1000; Cell Signaling Technology) immunoblots, membranes were blocked in $6 \%$ nonfat milk/TBST (10 mm Tris-HCl, pH 8.0, $150 \mathrm{~mm} \mathrm{NaCl}, 0.05 \%$ Tween 20) at $37^{\circ} \mathrm{C}$ for $30 \mathrm{~min}$, and then probed for $1 \mathrm{~h}$ at $37^{\circ} \mathrm{C}$ and overnight at $4^{\circ} \mathrm{C}$ with primary antibodies. For pTrkB (1:1000; a gift from R. Rajagopal and M. V. Chao, New York University, New York, NY) and TrkB (1:1000; Santa Cruz Biotechnology, Santa Cruz, CA) immunoblots, membranes were incubated in $0.25 \%$ gelatin/TBST ( $10 \mathrm{~mm}$ Tris- $\mathrm{HCl}, \mathrm{pH} 8.0,150 \mathrm{~mm}$ $\mathrm{NaCl}, 0.05 \%$ Tween 20 ) at $37^{\circ} \mathrm{C}$ for $30 \mathrm{~min}$, and then probed for $1 \mathrm{~h}$ at $37^{\circ} \mathrm{C}$ and overnight at $4^{\circ} \mathrm{C}$ with primary antibodies. Some membranes were incubated with two additional pTrk antibodies [pTrk against Y490 (Genetex, San Antonio, TX) and pTrk against Y674/675 (gifted from R. Segal, Harvard University, Cambridge, MA)] to confirm the presence of pTrk bands and determine whether phosphorylation occurred at multiple sites on the Trk protein. Membranes were then washed three times for 5 min each in TBST and subsequently probed for $1 \mathrm{~h}$ with secondary antibodies (goat anti-rabbit, 1:4000; Santa Cruz Biotechnology). The immunoreactive bands were visualized using SuperSignal West Pico Chemiluminescent Substrate (Pierce Biotechnology) and the Autochemi detection system (UVP, Upland, CA). To ensure equal protein loading, blots were reprobed with anti-glyceraldehyde-3-phosphate dehydrogenase (GAPDH; 1:1000; Santa Cruz Biotechnology).

Peptide blocking experiments were performed to determine whether the bands identified by the TrkB antibody represented nonspecific binding. TrkB antibody (SC-119) and its blocking peptide were obtained from Santa Cruz Biotechnology. The primary antibody and blocking peptide (1:40 ratio of antibody/peptide) were incubated together in blocking solution overnight at $4^{\circ} \mathrm{C}$ before being used for Western analysis.

Deglycosylation of TrkB. Trk proteins have multiple glycosylation sites, which increase their molecular weight from a core protein $(\sim 50-60$ $\mathrm{kDa})$ to a mature isoform expressed on extracellular membranes $(\sim 140-$ $150 \mathrm{kDa}$ ) (Watson et al., 1999). PNGase digestion of C4 ventral spinal cords was performed to determine whether the bands identified as TrkB proteins on Western analysis were glycosylated. The digestion protocol has been published in full previously (Watson et al., 1999). Briefly, five C4 ventral spinal cords were homogenized in a $1.5 \mathrm{ml}$ of reaction buffer $[10 \times \mathrm{G} 7$ buffer, $300 \mu \mathrm{l} ; 10 \times$ denaturing buffer, $30 \mu \mathrm{l} ; 10 \% \mathrm{NP}-40$, double-distilled $\mathrm{H}_{2} \mathrm{O}\left(\mathrm{ddH}_{2} \mathrm{O}\right), 2.1 \mathrm{ml}$; New England Biolabs, Beverly, $\mathrm{MA}]$ and centrifuged $\left(7000 \times \mathrm{g}\right.$ at $4^{\circ} \mathrm{C}$ for $\left.10 \mathrm{~min}\right)$. The supernatant was boiled for $2 \mathrm{~min}$ at $100^{\circ} \mathrm{C}$ and then separated into two $600 \mu \mathrm{l}$ aliquots. After cooling, $5000 \mathrm{U}$ of PNGase (New England Biolabs) was added to one aliquot (digestion sample), and $10 \mu \mathrm{l}$ of $\mathrm{ddH}_{2} \mathrm{O}$ was added to the other aliquot (control sample). The aliquots were incubated at $37^{\circ} \mathrm{C}$ and sampled at $15 \mathrm{~min}$. Samples were immediately boiled to denature the enzyme and stored at $-80^{\circ} \mathrm{C}$ until prepared for TrkB Western analysis as described above.

BDNF ELISA. C4 ventral spinal BDNF protein concentration was measured using a commercially available ELISA kit (Quantikine BDNF ELISA; R \& D Systems, Minneapolis, MN) in nine rats that had received intrathecal CGS 21680 and six rats that had received intrathecal DMSO. All tissues were harvested at 120 min after CGS 21680 and prepared in RIPA buffer as described for Western analysis. All samples were diluted fourfold using calibrator diluent RD5K (R \& D Systems). A $100 \mu \mathrm{l}$ of assay diluent RD1S and $50 \mu \mathrm{l}$ of sample was added to each well. The plate was incubated for $2 \mathrm{~h}$ at room temperature. One hundred microliters of conjugate were then added to each well and incubated for $1 \mathrm{~h}$ at room temperature. The plate was then washed three times with prepared wash buffer (R \& D Systems). Two hundred microliters of substrate solution were added, and the plate was incubated for $30 \mathrm{~min}$ away from light. Fifty microliters of stop solution ( $R$ \& D Systems) were added to each well, and the plate was read in a plate reader using a $540 / 570 \mathrm{~nm}$ wavelength.

Immunohistochemistry. The cellular localization of TrkB and phospho-TrkB protein was evaluated in C4 spinal segments collected from rats $(n=4)$ at $120 \mathrm{~min}$ after intrathecal delivery of vehicle (DMSO) or CGS 21680 ( $n=2$ for each treatment). Rats were perfused transcardially with $0.01 \mathrm{~m}$ PBS, $\mathrm{pH} 7.4$, followed by $4 \%$ buffered paraformaldehyde, $\mathrm{pH}$ 7.4. The cervical spinal cords were removed and cryoprotected with $30 \%$ sucrose in $0.1 \mathrm{M}$ PBS, and $25 \mu \mathrm{m}$ transverse sections were cut using a freezing microtome. Four representative sections were selected for each animal. The sections were rinsed in $0.1 \mathrm{M}$ Tris-buffered saline with $0.1 \%$ Triton $\mathrm{X}-100$ (TBS-T), incubated in $1 \% \mathrm{H}_{2} \mathrm{O}_{2}$ for $30 \mathrm{~min}$, and rewashed in TBS-T. The sections were then incubated in 5\% normal goat serum for $1 \mathrm{~h}$ and overnight in rabbit polyclonal TrkB (1:1000; Santa Cruz Biotechnology) or rabbit polyclonal phospho-TrkB (1:500; courtesy of M. V. Chao). The sections were rewashed in TBS-T and incubated in biotinylated goat anti-rabbit antibody (1:1000; Vector Laboratories, Burlingame, CA) for $1 \mathrm{~h}$. Conjugation with avidin-biotin complex (1: 100; Vectastain Elite ABC kit; Vector Laboratories) was followed by visualization with the mixture $3,3^{\prime}$-diaminobenzidine-hydrogen peroxidase with nickel chloride solution (DAB Substrate Kit; Vector Laboratories). To identify cell morphology, all sections were counterstained with $0.1 \%$ cresyl-violet, dehydrated, and coverslipped. Sections incubated without primary or secondary antibodies served as negative control.

Double immunofluorescence was used to examine adenosine 2a receptor expression near phrenic motoneurons. Parallel sets of sections from each C4 spinal segment were blocked with 5\% donkey serum in 0.1 $\mathrm{M}$ TBS-T for $1 \mathrm{~h}$ and incubated overnight in a combination of adenosine 2a receptor antibody (1:500; mouse monoclonal; Millipore) with antibody against the mature neuronal marker ChAT (sheep polyclonal; 1:500; Millipore). Sections were washed with TBS-T and then incubated with the secondary antibodies conjugated to donkey anti-mouse (red fluorescent, Alexa 495; 1:200; Invitrogen) and donkey anti-sheep (green fluorescent, Alexa 488; 1:200, Invitrogen) for $2 \mathrm{~h}$ at room temperature. After extensive washes, sections were mounted with antifade medium (Invitrogen) and examined under a fluorescent microscope (E600; Nikon, Osaka, Japan). All images were captured and analyzed with a digital camera (SPOT II; Diagnostic Instruments, Sterling Heights, MI). Photo- 
shop software (version 7.0; Adobe Systems, San Jose, CA) was used to create the photomicrographs. Equivalent adjustments to tone scale, gamma, and sharpness were made across all images.

Spinal cord hemisection. Details of the surgical technique have been published previously (Golder et al., 2003; Golder and Mitchell, 2005). Rats were anesthetized, intubated, and mechanically ventilated. Surgical exposure of the $\mathrm{C} 2$ spinal segment permitted aspiration of spinal tissue leaving a 1-mm-long left-sided hemisection. All animals received postsurgical pain control as previously described. Rats recovered for 8 weeks after surgery before use in the whole-body plethysmography experiments.

Whole-body plethysmography. To investigate whether A2a receptor activation improves ventilatory function in spinally injured rats, ventilation was measured using flow-through, barometric plethysmography before and after CGS 21680 administration. Uninjured and spinally injured rats were placed in a whole-body plethysmograph (model PLY3213; Buxco Electronics, Wilmington, NC). Pressurized air flowed through the chamber providing a bias airflow of $2 \mathrm{~L} / \mathrm{min}$, allowing control of inspired gas composition and preventing $\mathrm{CO}_{2}$ accumulation. A pressure calibration signal (obtained before placing a rat into the chamber), plethysmograph temperature, rat body temperature, ambient and chamber pressures, and rat body mass were used in the Drorbaugh and Fenn equation (Drorbaugh and Fenn, 1955) to calculate breath-by-breath minute ventilation $\left(\mathrm{ml} \cdot \mathrm{min}^{-1} \cdot 100 \mathrm{~g}^{-1}\right)$, frequency (breaths/min), and tidal volume (ml/100 g) (Biosystems XA software; Buxco Electronics, Wilmington, NC). Baseline recordings were obtained for at least $2 \mathrm{~h}$, during which rats alternated between awake and subjective sleep. Rats were then removed from the chamber and received three injections of CGS 21680 (50 $\mu \mathrm{M}$, i.p.; each separated by $5 \mathrm{~min}$ ). Preliminary experiments in anesthetized rats revealed a dose of CGS 21680 that had minimal effects on arterial blood pressure while eliciting A2a-induced phrenic motor facilitation. After the third intraperitoneal injection, rats were returned to the chamber and ventilatory recordings continued for an additional 150 min. Plethysmography data were analyzed in $10 \mathrm{~min}$ bins during subjective sleep during baseline conditions and at 60 and $120 \mathrm{~min}$ after CGS 21680 administration. Comparisons between baseline and postdrug ventilatory measurements were matched for body position during sleep (curled lateral or head-tucked sternal) because preliminary date demonstrated an effect of body position on the pattern of breathing.

Statistical analysis. Assumptions of normality and equal variance were tested before parametric analyses were performed. When these assumptions could not be confirmed, nonparametric analysis was performed with Kruskal-Wallis ANOVAs followed by Mann-Whitney $U$ tests. Otherwise, statistical inferences were based on a two-way ANOVA with a repeated-measures design [factors: time (repeated measures) and treatment], with individual comparisons made using Student-NewmanKeuls post hoc test when indicated. Western analysis data were compared between treatment groups and vehicles using one-sample $t$ tests. Differences were considered significant if $p<0.05$. All values are expressed as mean \pm SEM.

\section{Results}

\section{Cervical A2a receptor activation elicits persistent phrenic motor facilitation}

Phrenic inspiratory burst amplitude increased above baseline values for $>120$ min after cervical (C4) intrathecal administration of the A2a receptor agonist CGS $21680\left(2 \mu \mathrm{g} \cdot \mathrm{kg}^{-1} ; 50 \mu \mathrm{M}\right)$ in anesthetized rats (Fig. 1 $1, b$ ). Phrenic burst frequency (fictive respiratory rate) also increased to a small extent (baseline, $41 \pm 1$; $120 \mathrm{~min}, 44 \pm 1 ; p<0.05)$, but this effect was independent of drug treatment. To confirm the role of cervical spinal A2a receptors near phrenic motoneurons (Fig. 1c) in CGS 21680-induced phrenic motor facilitation, rats were pretreated with cervical intrathecal MSX-3, a specific A2a receptor antagonist. MSX-3 (10 $\mu \mathrm{M}$ ) abolished A2a-induced phrenic motor facilitation (Fig. 1b), but only when administered before CGS 21680. When MSX-3 was administered 120 min after CGS 21680, A2a-induced phrenic
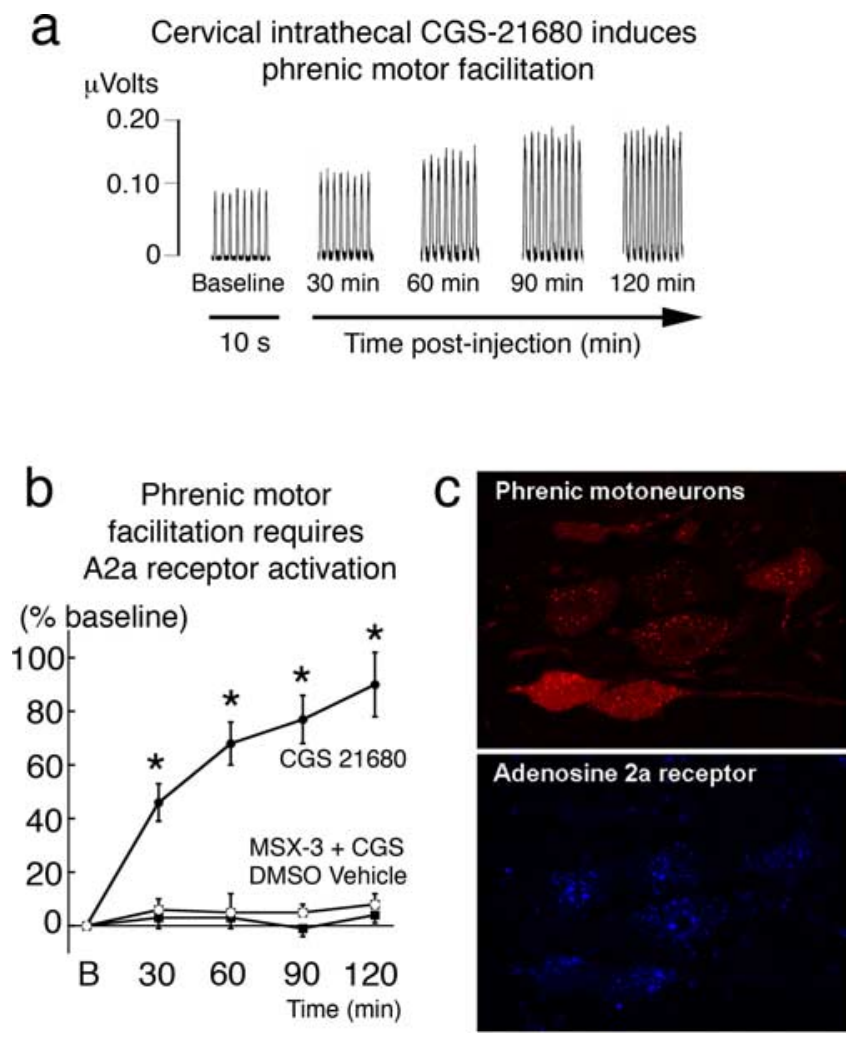

Figure 1. (4 spinal A2a receptor activation facilitates phrenic motor output in anesthetized rats. $\boldsymbol{a}$, Representative traces of integrated phrenic discharge before and $120 \mathrm{~min}$ after intrathecal injection of the A2a receptor agonist, $\operatorname{CGS} 21680\left(2 \mu \mathrm{g} \cdot \mathrm{kg}^{-1}\right) \cdot \boldsymbol{b}$, Average data depicting the percentage change in phrenic burst amplitude after intrathecal injections of CGS 21680 (filled circles; $n=12$ ), vehicle (DMSO; squares; $n=6$ ), and the A2a receptor antagonist, MSX-3 (130 $\mathrm{ng} \cdot \mathrm{kg}^{-1}$; open circles; $n=5$ ) followed by CGS 21680 (CGS). Intrathecal CGS 21680 significantly increased phrenic burst amplitude. MSX-3 blocks CGS 21680 effects on phrenic motor output, confirming that the effects result from A2a receptor activation. c, Immunofluorescence and representative photomicrographs of back-labeled 44 phrenic motoneurons and $A 2 a$ receptor protein. A2a receptor protein was localized on and near phrenic motoneurons. *Significantly different from other groups $(p<0.05)$. Data are mean \pm SEM.

motor facilitation was unaffected $(n=3$; CGS $21680+$ MSX-3, $87 \pm 16 \%$ of baseline), suggesting that cervical spinal A2a receptor activation initiates, but does not maintain, phrenic motor facilitation in anesthetized rats. Alone, MSX-3 $(n=4)$ did not alter phrenic motor output compared with time controls (MSX-3, $9 \pm 7 \%$; time controls, $6 \pm 5 \%$, of baseline).

\section{A2a receptors strengthens spinal synaptic pathways to phrenic motoneurons}

Multiple factors influence phrenic motoneuron activity (Feldman and McCrimmon, 2002), including peripheral and central chemoreflexes. Thus, it is essential to maintain precise blood gas regulation during studies of respiratory plasticity (Mitchell and Johnson, 2003). Measurements of arterial $\mathrm{pCO}_{2}$ and $\mathrm{pO}_{2}$ were similar across treatment groups and did not change over time (data not shown). Mean arterial blood pressure decreased with time, but the change was similar across all experimental groups (data not shown). To assure that A2a-induced phrenic motor facilitation was not the result of drug reaching the brainstem, we recorded respiratory activity in the hypoglossal nerve after cervical intrathecal CGS 21680. No hypoglossal facilitation ( $-4 \pm 9 \%$ of baseline; $n=6$ ) was observed at the standard dose of CGS 21680. On the other hand, A2a-induced hypoglossal motor facilitation could be elicited at higher doses of CGS 21680 (5 mM; 


\section{a Phrenic evoked compund action potentials}

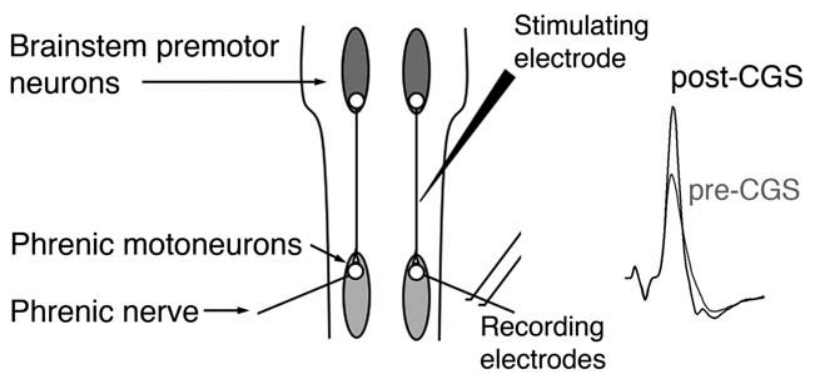

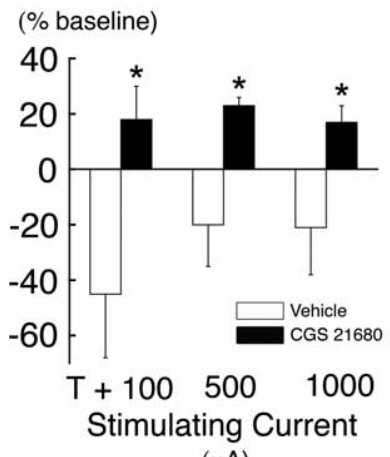

$(\mu \mathrm{A})$

\section{b Evoked potential facilitation}

\section{A2a-induced evoked vs. spontaneous facilitation}

(\% baseline)

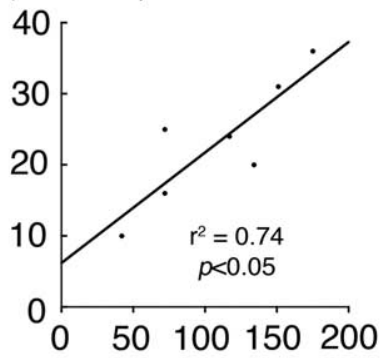

Spontaneous facilitation (\% baseline)
Figure 2. (4 spinal A2a receptor activation strengthens synaptic pathways to phrenic motoneurons. $\boldsymbol{a}$, Schematic representation of stimulating and recording electrode positions and representative phrenic evoked potentials. A stimulating electrode was positioned in the $\mathrm{C} 2$ ventrolateral funiculus. Stimulus current-evoked short-latency potentials were recorded from the phrenic nerve ipsilateral to the stimulating electrode. $\boldsymbol{b}$, Average data depicting the percentage change in phrenic evoked potential amplitude at multiple stimulating currents after intrathecal CGS 21680 ( $n=7$ ) or vehicle (DMSO; $n=5$ ) injection in anesthetized rats. Intrathecal CGS 21680 elicited significant facilitation of phrenic evoked potential amplitude, suggesting that $A 2 a$ receptor activation strengthens short-latency (putative monosynaptic) connections to phrenic motoneurons. T, Threshold current. c, Regression analysis of A2a-induced facilitation of the evoked response versus spontaneous phrenic burst facilitation from the same rats. The magnitude of evoked facilitation positively correlated with the magnitude of spontaneous phrenic facilitation. *Significantly different from other groups $(p<0.05)$. Data are mean \pm SEM.

$155 \pm 22$ of baseline; $n=2$ ), suggesting that hypoglossal motoneurons express A2a-induced motor facilitation and are an appropriate control for supraspinal drug spread.

Synaptic plasticity can strengthen spinal pathways to phrenic motoneurons after intermittent hypoxia, thereby contributing to pLTF (Fuller et al., 2003; Baker-Herman et al., 2004; Golder and Mitchell, 2005). To demonstrate similar synaptic plasticity during A2a-induced phrenic motor facilitation, short-latency phrenic potentials evoked by electrical stimulation of the ventrolateral funiculus were recorded during hypocapnia-induced apnea from anesthetized rats before and after cervical spinal A2a receptor activation (Fig. $2 a$ ). Facilitation of phrenic evoked potentials was observed after A2a receptor activation (Fig. 2b). A strong, positive correlation existed between A2a-induced evoked potential facilitation and phrenic motor facilitation (Fig. $2 c$ ), suggesting that strengthened spinal synaptic pathways (vs increased descending respiratory drive) underlie A2a-induced facilitation of spontaneous phrenic motor activity.

\section{A2a receptor activation transactivates TrkB protein in the} cervical ventral horn

A2a receptor activation has been reported to phosphorylate the tyrosine kinase domain of Trk receptors in PC12 cells in the absence of neurotrophins and induces neurotrophin-like effects on cellular function (Lee and Chao, 2001; Lee et al., 2002; Rajagopal et al., 2004). To determine whether A2a-induced phrenic motor facilitation requires tyrosine kinase activation, the tyrosine kinase inhibitor K252a was delivered intrathecally before CGS 21680. Because TrkB receptors are the primary neurotrophin receptor expressed in spinal motoneurons (Yan et al., 1993), the dose of K252a was selected based on its ability to inhibit BDNF effects on phrenic motor output (Baker-Herman et al., 2004). K252a $(150 \mu \mathrm{M})$ inhibited A2a-induced phrenic motor facilitation at 60 min after CGS 21680 administration and beyond, but not at earlier time points (Fig. $3 a)$. Alone, K252a $(n=3)$ did not alter phrenic motor output compared with time controls (K252a, $-5 \pm 8 \%$; time controls, $6 \pm 5 \%$, of baseline). Thus, A2ainduced phrenic motor facilitation has an early and late phase, and only the late phase appears to require receptor tyrosine kinase activation.

TrkB and phosphorylated TrkB protein were identified by immunoblots of $\mathrm{C} 4$ ventral spinal tissue, a region that contains the greatest density of phrenic motoneurons. Two TrkB splice variants have been reported in rat motoneurons (Armanini et al., 1995). Three TrkB protein isoforms were observed in the $C 4$ ventral cord, including $\operatorname{TrkB}_{150}, \operatorname{TrkB}_{100}$, and $\operatorname{TrkB}_{80}$ (Fig. $3 b$ ). These same bands were confirmed with a second TrkB antibody (from a different commercial source and directed to a different epitope on TrkB), and were absent after peptide blocking experiments (Fig. 3e). Trk protein is glycosylated after its initial synthesis, before insertion into the neuronal membrane (Watson et al., 1999). Thus, we performed PNGase deglycosylation experiments. PNGase digestions shifted TrkB bands toward a core protein of $\sim 52 \mathrm{kDa}$ (Fig. $3 f$ ).

$\operatorname{TrkB}_{150}$ was phosphorylated after intrathecal BDNF administration ( $n=2$; phospho-TrkB-to-TrkB ratio increased $43 \pm 10 \%$, compared with vehicle) and is likely the full-length catalytic form of TrkB protein expressed on extracellular membranes. TrkB ${ }_{100}$ was not detected by the phospho-TrkB antibodies and is likely the truncated isoform lacking the tyrosine kinase domain (Armanini et al., 1995). Lower-molecular-weight Trk isoforms have been described as hypoglycosylated immature protein, intracellularly localized, and inaccessible for neurotrophin binding (Watson et al., 1999; Mutoh et al., 2000; Rajagopal et al., 2004). Similarly, $\operatorname{TrkB}_{80}$ may represent an intracellular, hypoglycosylated TrkB isoform that is unavailable to BDNF. Indeed, the $\operatorname{TrkB}_{80}$ phosphorylation state was unaffected by intrathecal $\operatorname{BDNF}(n=2$; pTrkB-to-TrkB ratio, $-13 \pm 5 \%$, compared with vehicle).

Cervical A2a receptor activation increased $\operatorname{TrkB}_{80}$, but not $\operatorname{TrkB}_{150}$, phosphorylation in the $\mathrm{C} 4$ ventral cord (Fig. $3 c$ ); TrkB phosphorylation state was detected with a phospho-TrkB antibody for the Y-816 phosphorylation site (gift from R. Rajagopal and M. V. Chao). Selective phosphorylation of $\operatorname{TrkB}_{80}$ was confirmed with two other phospho-TrkB antibodies directed against the Y-490 and Y-674/675 phosphorylation sites (data not shown). Thus, A2a receptor activation selectively phosphorylates the $\operatorname{TrkB}_{80}$ isoform, and does so at multiple tyrosine residues. In this study, we normalized phospho-TrkB expression to total TrkB protein (Figs. 3, 5). However, phosphorylated proteins can also be normalized to loading controls, such as GAPDH. Regardless of the method used, A2a receptor activation increased phospho-TrkB80 expression in C4 ventral spinal segments 

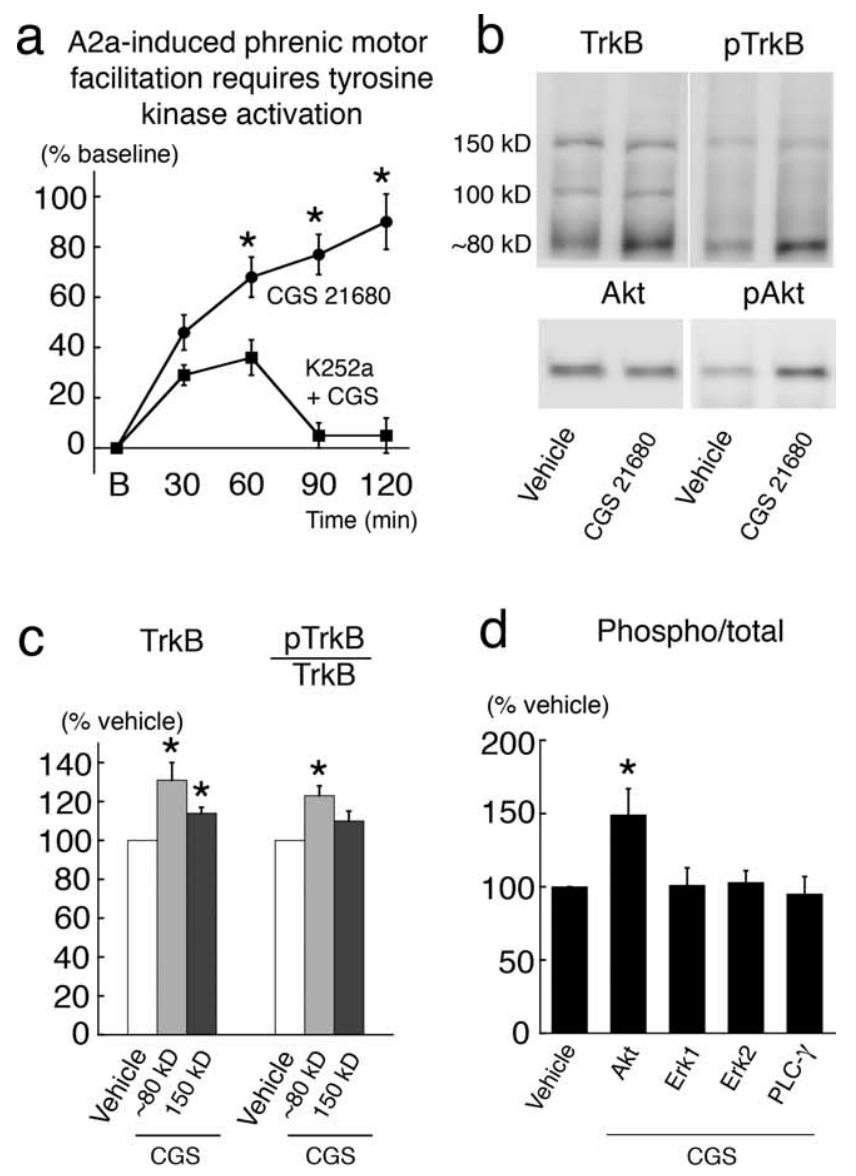

\section{d Phospho/total}
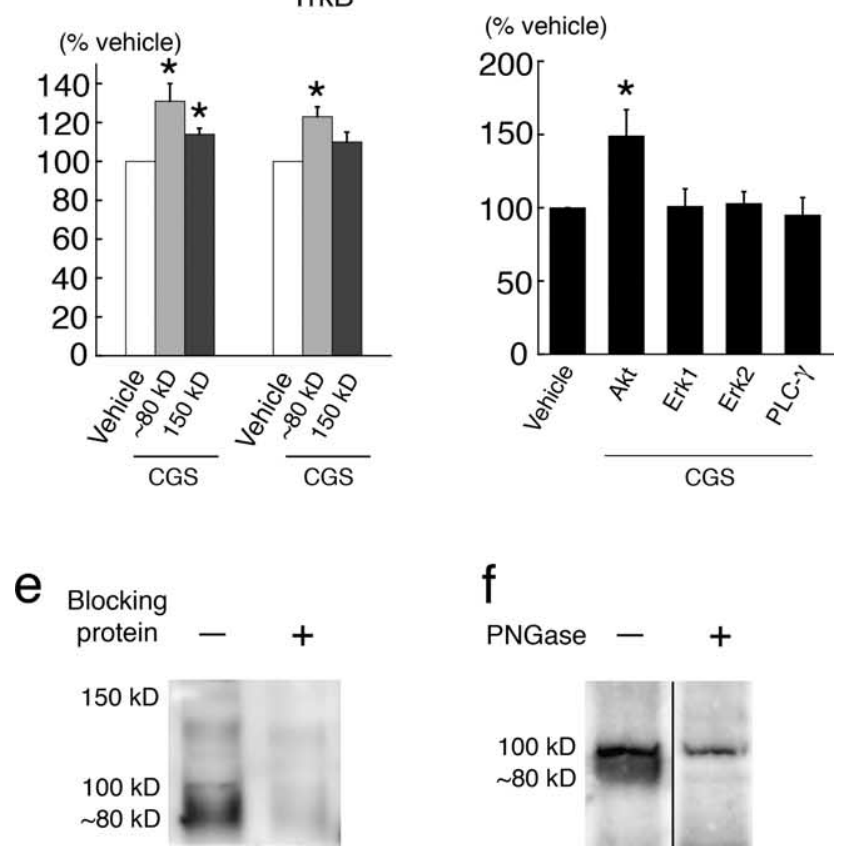

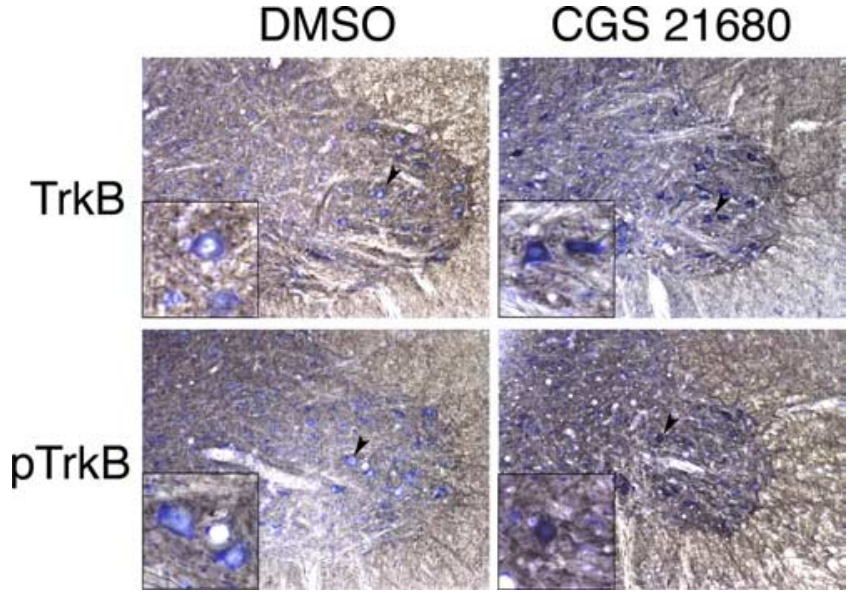

Figure 4. Representative photomicrographs of ventral C4 spinal cords collected from rats perfused at 120 min after intrathecal vehicle (DMSO) or CGS 21680. Top, Immunohistochemical photomicrographs of TrkB protein (gray-black) with a Nissl counterstain (blue) (400X). TrkB protein was observed near large neurons (presumptive phrenic motoneurons) in the ventral gray matter. Intrathecal CGS 21680 increased TrkB protein immunoreactivity around these motoneurons, but most notably within neuron somata. Bottom, Immunohistochemical examination for pTrkB protein $(400 \times)$. pTrkB protein was observed near, and sometimes within, presumptive motoneurons. Intrathecal CGS 21680 increased TrkB immunoreactivity around and, most notably, within neuron somata. Arrows indicate presumptive motoneurons. Insets, enlarged area near arrows $(600 \times)$.

(phospho-TrkB80/total TrkB80, $24 \pm 5 \%$; phospho-TrkB80/ GAPDH, $69 \pm 16 \%$; $p<0.05$ ). To confirm and localize TrkB activation within the $\mathrm{C} 4$ ventral cord, spinal sections were exposed to the same $\mathrm{pTrkB}$ antibody. $\mathrm{pTrkB}$ protein was observed throughout the ventral gray matter in small fibers and, to a lesser degree, within presumptive motoneuron somata (Fig. 4a). Spinal $\mathrm{A} 2 \mathrm{a}$ receptor activation increased $\mathrm{pTrkB}$ immunoreactivity within motoneuron somata and in adjacent fibers.

Similar to in vitro studies using PC-12 cells (Lee et al., 2002; Rajagopal et al., 2004), Akt phosphorylation (but not ERK-1, ERK-2, or PLC- $\gamma$ ) was increased after cervical A2a receptor activation (Fig. $3 d$ ). The A2a-induced phosphorylation pattern differed from intrathecal BDNF, where Akt, ERK-1, and ERK-2 were all phosphorylated (pAkt-to-Akt ratio, $125 \pm 2 \%$; pERK-1to-ERK-1 ratio, $122 \pm 30 \%$; ERK-2-to-ERK-2 ratio, $118 \pm 7 \%$, compared with vehicle; $n=3$ ).

TrkB activation was not attributable to new BDNF synthesis, because BDNF concentration in the ventral $\mathrm{C} 4$ cord was unaffected by A2a receptor activation (control, $412 \pm 28 ; n=9$; CGS $21680,398 \pm 12 \mathrm{ng} / \mathrm{g} ; n=6$ ); this result was confirmed with BDNF immunoblots (CGS 21680, $149 \pm 75 \%$, compared with vehicles; $n=6$ ). Furthermore, siRNAs directed at BDNF mRNA to prevent translation of new BDNF protein were ineffective at blocking A2A receptor-induced phrenic motor facilitation (see below). Collectively, these data demonstrate cervical A2a receptor-induced transactivation of TrkB protein in the $\mathrm{C} 4$ spinal cord does not require new BDNF synthesis (unlike phrenic longterm facilitation after intermittent hypoxia).

\section{New TrkB synthesis is necessary for A2a-induced phrenic motor facilitation}

New protein synthesis contributes to multiple forms of synaptic plasticity (Sajikumar et al., 2005; White-Grindley and Si, 2006), including pLTF after intermittent hypoxia (Baker-Herman et al., 2004). New protein synthesis is also necessary for A2a receptorinduced phrenic motor facilitation in anesthetized rats, because it 

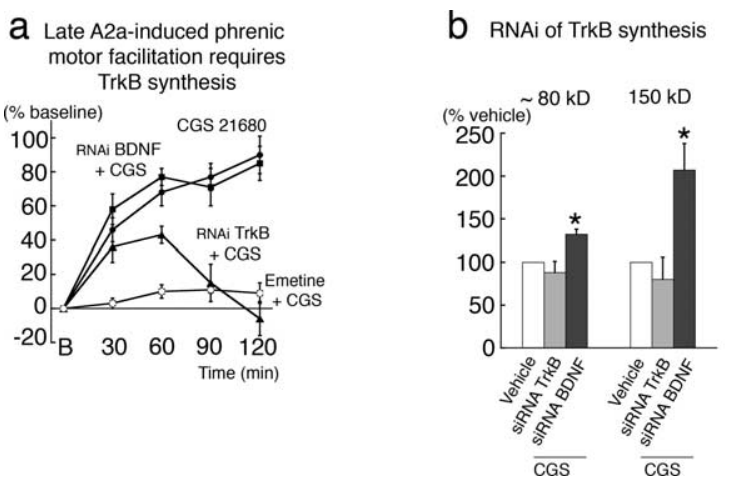

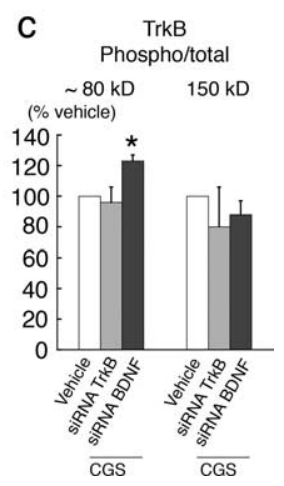

Figure 5. New TrkB protein synthesis near phrenic motoneurons is necessary for A2a-induced facilitation of phrenic motor output. $\boldsymbol{a}$, Average data depicting percentage change in phrenic burst amplitude after intrathecal CGS 21680 only (squares), and in rats that received intrathecal siRNA targeting either BDNF mRNA (open circles; $n=5$ ) or TrkB mRNA (filled circles; $n=5$ ) or emetine (open circles; $n=3$ ) $2 \mathrm{~h}$ before intrathecal CGS 21680 injection. RNAi targeting TrkB mRNA blocked late A2a-induced phrenic motor facilitation. RNAi targeting BDNF mRNA did not alter A2a-induced facilitation. $\boldsymbol{b}$, Average data for percentage change in TrkB protein (normalized to GAPDH) for the study described in $\boldsymbol{a}$. RNAi to BDNF mRNA did not block A2a-induced TrkB synthesis. However, TrkB synthesis was blocked by pretreatment with siRNAs targeting TrkB mRNA. c, Average data for percentage change in pTrkB protein (normalized to TrkB) for the study described in $\boldsymbol{a}$. RNAi to BDNF mRNA did not block A2a-induced selective phosphorylation of immature TrkB isoforms. Low-molecular-weight TrkB protein was not phosphorylated when an siRNA targeting TrkB mRNA was administered before intrathecal CGS 21680. *Significantly different from other groups ( $p<$ 0.05). Data are mean \pm SEM.

was abolished by intrathecal administration of the translation inhibitor emetine (Fig. $5 a$ ).

Immunoblots revealed increased TrkB protein levels after A2a receptor activation, suggesting new TrkB synthesis (Fig. 3b,c) similar to reports in PC12 cells after A2a receptor activation. C4 spinal sections were examined for TrkB immunoreactivity in the ventral gray matter. TrkB protein was observed primarily in small fibers and, occasionally, in presumptive motoneuron somata (Fig. 4b). A2a receptor activation increased TrkB immunoreactivity in the ventral gray matter, including within presumptive motoneuron somata.

To determine whether new TrkB synthesis was necessary for A2a-induced phrenic motor facilitation, we used translational inhibition via RNAi directed against TrkB mRNA. RNAi blocked phrenic motor facilitation, but only 60 min after CGS 21680 administration and beyond (Fig. $5 a$ ). These results again suggest mechanistically distinct phases of A2a-induced phrenic motor facilitation: (1) a late phase requiring tyrosine kinase activation and new TrkB protein synthesis; and (2) an early phase requiring new protein synthesis, but not tyrosine kinase activation or new TrkB synthesis. As a control, two siRNA sequences (50 nM total with Oligofectamine) directed against BDNF mRNA [and known to block intermittent hypoxia-induced BDNF synthesis in $\mathrm{C} 4$ spinal segments (Baker-Herman et al., 2004)], were administered intrathecally before $\mathrm{A} 2 \mathrm{a}$ receptor activation, and phrenic motor facilitation was unaffected (Fig. 5a). In addition, we used an siRNA with at least four mismatches with all known human, mouse, and rat genes (siCONTROL NonTargeting siRNA \#2; Dharmacon) as a control sequence before injecting CGS 21680 intrathecally. The siCONTROL siRNA also did not alter A2ainduced phrenic motor facilitation (facilitation, $120 \pm 13 \%$ above baseline amplitude) compared with CGS 21680 alone. Thus, siRNAs targeting TrkB mRNA are selective in their effects on A2a-induced phrenic motor facilitation. Furthermore, the mechanisms of A2a-induced phrenic motor facilitation and intermittent hypoxia phrenic long-term facilitation converge only downstream from TrkB signaling.

Western analyses of ventral C4 spinal segments exposed to lier reports, spinally injured rats in the current study maintained minute ventilation by using a rapid shallow breathing pattern (uninjured, $f=71 \pm 3 \mathrm{~min}^{-1}$; $\mathrm{VT}=6.8 \pm 0.3 \mathrm{ml} \cdot \mathrm{kg}^{-1}$; pulmonary ventilation $=459 \pm 18 \mathrm{ml} \cdot \mathrm{kg}^{-1} \cdot \mathrm{min}^{-1} ; n=6 ; \mathrm{C} 2$ spinally hemisected, $f=86 \pm 2 \mathrm{~min}^{-1}$; VT $=4.9 \pm 0.3 \mathrm{ml} \cdot \mathrm{kg}^{-1}$; minute ventilation $\left.=411 \pm 15 \mathrm{ml} \cdot \mathrm{kg}^{-1} \cdot \min ^{-1} ; n=3\right)$. A2a receptor activation increases VT in uninjured rats and restores normal tidal volumes in spinally hemisected rats 60 and $120 \mathrm{~min}$ after intraperitoneal CGS $21680\left(100 \mu \mathrm{g} \cdot \mathrm{kg}^{-1} ; 50 \mu \mathrm{M}\right.$ administered in three doses separated by $5 \mathrm{~min}$ ). CGS 21680 increased pulmonary ventilation above baseline values in spinally injured rats at 60 and $120 \mathrm{~min}$ after administration, and above DMSO vehicle control rats at all time points (Fig. $6 a, b$ ). The relative magnitude and time course of A2a-induced ventilatory facilitation was similar in control and hemisected rats. Increased VT and $f$ (uninjured, 60 min postdrug $f=16 \pm 10 \%$; C2 spinally hemisected, 60 min postdrug $f=19 \pm 6 \%$; of predrug value) both contributed to ventilatory facilitation at $60 \mathrm{~min}$ after intraperitoneal CGS 21680, whereas only VT remained elevated above baseline values at $120 \mathrm{~min}$ (frequency uninjured, $120 \mathrm{~min}$ postdrug $f=0 \pm 1 \%$; C2 spinally hemisected, $120 \mathrm{~min}$ postdrug $f=1 \pm$ $1 \%$; of predrug value) (Fig. $6 a-c$ ). Thus, A2a receptor activation increases inspiratory volume in unanesthetized intact and spinally hemisected rats, restoring inspiratory volumes toward normal in injured rats (uninjured, VT $=6.8 \pm 0.3 \mathrm{ml} \cdot \mathrm{kg}^{-1} ; \mathrm{C} 2$ spinally hemisected, $\left.5.8 \pm 0.2 \mathrm{ml} \cdot \mathrm{kg}^{-1}\right)$. The percentage change in tidal volume after systemic CGS 21680 was similar in uninjured and C2 hemisected rats (uninjured, $21 \pm 3 \%$; injured, $18 \pm$ $2 \%$; of baseline values). An important caveat is that spontaneously breathing rats decrease arterial $\mathrm{pCO}_{2}$ levels during ventilatory facilitation, thereby minimizing the apparent A2a-induced ventilatory facilitation caused by inhibitory chemoreceptor feedback (Olson et al., 2001). If arterial pCO$_{2}$ levels were controlled, predicted changes in VT are larger.

\section{Discussion}

Collectively, these results demonstrate that $\mathrm{G}_{\mathrm{s}}$-protein-coupled A2a receptors induce new TrkB protein synthesis and transacti- 
a
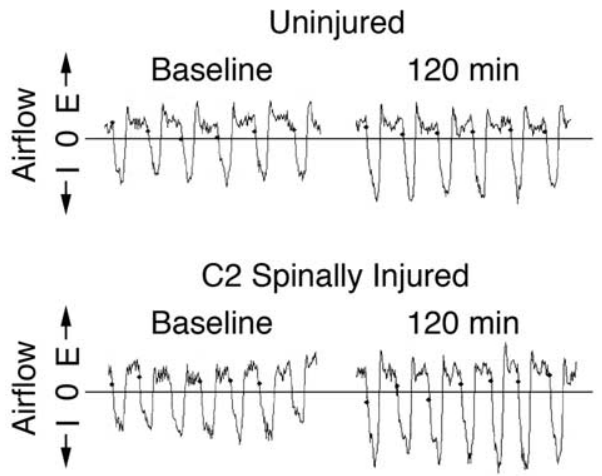

\section{b A2a-induced ventilatory facilitation}

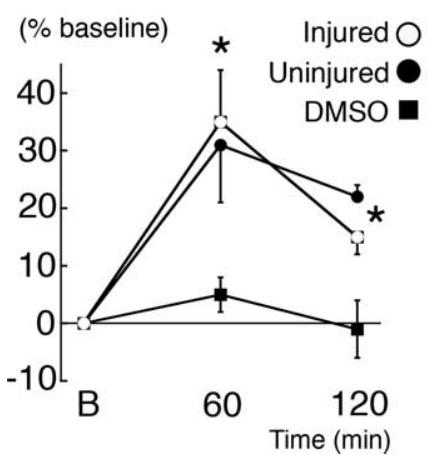

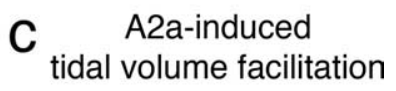

(\% baseline)

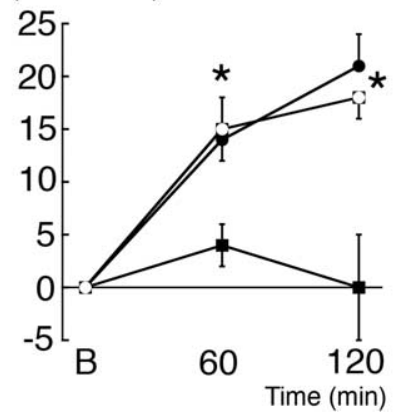

Figure 6. A2a receptor activation with systemic CGS 21680 increases tidal volume in uninjured and spinally injured unanesthetized rats. $\boldsymbol{a}$, Representative airflow traces measured in a whole-body plethysmograph from an uninjured (top trace) and C2 spinally hemisected rat (bottom trace) at 8 weeks after injury, during baseline breathing, and 120 min after intraperitoneal CGS $21680\left(100 \mu \mathrm{g} \cdot \mathrm{kg}^{-1}\right)$. I, Inspiration; E, expiration. b, c, Average data for percentage change in minute pulmonary ventilation (frequency $\times$ tidal volume) and tidal volume from baseline values after intraperitoneal CGS 21680 (uninjured, filled circles; $n=4$; injured, open circles; $n=4$ ) or vehicle (DMSO; squares; $n=4)$. Systemic CGS 21680 elicited ventilatory facilitation with a time course similar to phrenic motor facilitation that was primarily a result of increased tidal volume. *Significantly different from other groups $(p<0.05)$. Data are mean \pm SEM

vation of an immature TrkB isoform in cervical spinal regions associated with respiratory motor control (Fig. 7). The functional consequence of TrkB transactivation in or near phrenic motoneurons is a robust phrenic motor facilitation of similar duration and magnitude to BDNF-dependent phrenic long-term facilitation after acute intermittent hypoxia. The ability to simulate BDNF with a small, more easily delivered molecule suggests that A2a receptor agonists have considerable potential in the treatment of respiratory motor deficits caused by, for example, cervical spinal injury.

Interactions between $\mathrm{G}_{\mathrm{s}}$-protein-coupled receptors and Trk receptors have been described in vitro (Lee and Chao, 2001; Lee et al., 2002; Rajagopal et al., 2004). For example, A2a receptor agonists increase cell survival in cell cultures by activating immature Trk receptors (Rajagopal et al., 2004), which are restricted in their distribution to intracellular membranes (Watson et al., 1999; Mutoh et al., 2000). Intracellular Trk protein is hypoglycosylated and has a lower molecular weight than mature Trk protein at the cell surface. Low-molecular-weight $(\sim 79 \mathrm{kDa})$ TrkB protein has been previously described in the rat spinal cord (Skup et al., 2002), consistent with our conclusion that spinal A2a receptor activation phosphorylated a low-molecular-weight $(\sim 80 \mathrm{kDa})$ TrkB isoform. Our conclusion that the $80 \mathrm{kDa}$ band represents immature TrkB protein is supported by multiple observations, including the following: (1) multiple TrkB and phospho-TrkB antibodies targeting different epitopes of TrkB protein identify the same band, (2) the band is absent when a blocking peptide is applied to the TrkB antibody, (3) the $\sim 80 \mathrm{kDa}$ band (or bands) represent a glycosylated protein that converges toward a lowmolecular-weight band after deglycosylation, and (4) a similar band is reported by others in rat spinal cord and in PC-12 cells that overexpress TrkB. Collectively, our data strongly suggest that A2a receptor activation induces new TrkB synthesis and selectively phosphorylates an immature, likely intracellular TrkB isoform within cervical spinal regions associated with the phrenic motor nucleus.

A2a-induced Trk signaling requires new protein synthesis and tyrosine kinase activation in PC12 cells (Lee et al., 2002). In agreement, new protein synthesis is necessary for A2a receptorinduced phrenic motor facilitation, because the translation inhibitor emetine blocked the response. On the other hand, because tyrosine kinase inhibition with $\mathrm{k} 252 \mathrm{a}$ and RNAi targeting TrkB mRNA block only a late phase of the facilitation, at least two distinct mechanisms must give rise to phrenic motor facilitation after A2a receptor activation. An important caveat limiting interpretation of this study is that K252a inhibits multiple kinases; consequently, some K252a effects may reflect inhibition of receptor tyrosine kinases other than $\operatorname{TrkB}$, or possibly other kinases. Nevertheless, the critical role of Trk receptor signaling is supported by evidence from the RNAi experiments, because siRNAs targeting TrkB mRNA (but not BDNF mRNA) reduced new $\operatorname{TrkB}_{80}$ synthesis, the increase in $\operatorname{TrkB}_{80}$ phosphorylation, the increase in Akt phosphorylation, and phrenic motor facilitation. Increasing intracellular TrkB protein can induce constitutive Trk signaling (Watson et al., 1999) in the absence of ligand, possibly because increased Trk monomer concentrations enable autodimerization and subsequent phosphorylation.

A2a-induced Trk signaling occurs in the absence of neurotrophin-Trk interactions, has a slow onset $(>60 \mathrm{~min})$, and selectively activates PI3-kinase/Akt signaling in PC12 cells (Huang and Reichardt, 2003). Similarly, A2a-induced phrenic motor facilitation occurs without new BDNF synthesis; although we cannot rule out an involvement of BDNF-TrkB interactions, several lines of evidence argue against this possibility: (1) BDNF protein concentration did not change after A2a receptor activation; (2) RNAi to BDNF mRNA did not alter A2a-induced phrenic motor facilitation; (3) BDNF selectively activates the mature, fully glycosylated $\mathrm{TrkB}_{150}$ isoform, whereas $\mathrm{A} 2$ a receptor activation selectively phosphorylates the $\operatorname{TrkB}_{80}$ isoform; and (4) BDNFinduced TrkB activation increases both Akt and ERK1/2 phosphorylation, whereas A2a receptor-induced TrkB activation increases Akt phosphorylation alone.

Similar mechanisms of A2a receptor-induced TrkB transactivation may be operative in motoneurons subserving other motor functions, such as locomotion and upper airway patency. For example, facilitation of respiratory motor output was observed in hypoglossal motoneurons after A2a receptor activation. Respiratory motor output to the tongue and other upper airway muscles plays a critical role in maintaining upper airway patency during breathing. When upper airway patency is compromised during sleep, varied forms of sleep disordered breathing result. Thus, A2a receptor activation may represent a novel therapy for snoring and/or sleep apnea, disorders that afflict a large proportion of the 


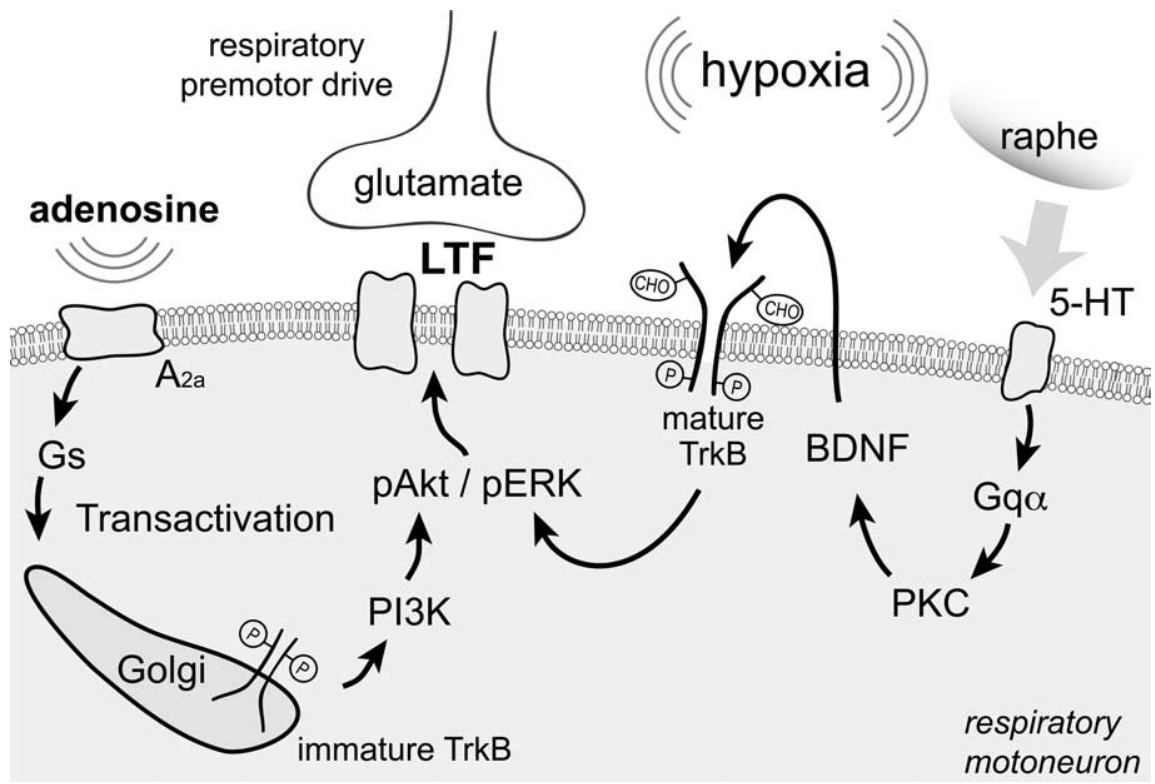

Figure 7. A schematic figure comparing and contrasting the proposed mechanisms contributing to intermittent hypoxiainduced phrenic LTF and adenosine A2a receptor-induced LTF. Intermittent hypoxia stimulates serotonin (5-HT) release from raphe-spinal terminals near phrenic motoneurons. Serotonin receptor and $\mathrm{G}_{\mathrm{q}}$-protein activation increases PKC activity, which in turn increases BDNF synthesis within phrenic motoneurons. BDNF is secreted extracellularly and binds to mature, fully glycosylated (CHO) TrkB receptors expressed on the outer cell membrane. BDNF phosphorylates $(\mathrm{P})$ mature TrkB receptors, which in turn strengthen excitatory glutamatergic synapses onto phrenic motoneurons via activated MAP kinases (pERK1/2). A2a receptor agonists activate $G_{s}$-protein and increase synthesis and phosphorylation of intracellular, hypoglycosylated, immature TrkB protein without the need for BDNF (transactivation). Phosphorylated intracellular TrkB strengthens excitatory glutamatergic synapses onto phrenic motoneurons via activated PI3K and protein kinase B (pAkt).

human population and for which there are currently no effective pharmacological therapeutic approaches.

Our data suggest that spinal mechanisms contribute to A2ainduced phrenic motor facilitation, at least in part, because spinal administration of CGS 21680 strengthened short-latency synaptic inputs onto phrenic motoneurons. Most respiratory bulbospinal neurons convey excitatory drive to phrenic motoneurons via monosynaptic connections in the rat. Thus, we propose that spinal $\mathrm{A} 2 \mathrm{a}$ receptor activation increases phrenic motor output by strengthening respiratory premotor inputs. On the other hand, the effects of spinal A2a receptor activation on spinal interneurons or other polysynaptic circuits were not investigated. Thus, it is possible that at least some of the facilitation observed in these experiments could result from modulation of other afferent inputs [i.e., intercostal-to-phrenic afferents (Eldridge et al., 1981, 1987; Bolser et al., 1988)].

We believe supraspinal mechanisms are not involved in A2ainduced phrenic motor facilitation because spinal administration of CGS 21680 did not change phrenic burst frequency (fictive respiratory rate), nor elicit hypoglossal motor facilitation (a respiratory motoneuron population located within the brainstem). On the other hand, in awake, freely behaving rats, intraperitoneal CGS 21680 did increase respiratory frequency in the short-term after drug administration. The mechanism(s) responsible for this frequency effect is (are) unknown.

In patients with high cervical spinal cord injury, enhancing respiratory motor function would markedly improve quality of life and survival (Winslow and Rozovsky, 2003). One viable approach to enhance respiratory motor function in spinal cord injury patients is to harness the inherent plasticity of residual synaptic inputs to respiratory motor neurons below an injury. For example, exogenous neurotrophins enhance synaptic strength in residual synaptic pathways to lumbar motoneurons after experimental spinal injuries (Arvanian et al., 2006). Similarly, BDNF may improve respiratory function below cervical spinal injury by strengthening surviving bulbospinal pathways to phrenic motoneurons. For example, acute intermittent hypoxia strengthens synaptic pathways to phrenic motoneurons and improves spontaneous phrenic activity by increasing endogenous BDNF synthesis and release (Golder and Mitchell, 2005). Thus, intermittent hypoxia may have beneficial effects in restoring respiratory motor function after cervical spinal injury. However, intermittent hypoxia is a nonspecific stimulus and may affect multiple physiological systems and, in excess, may induce severe morbidity such as systemic hypertension, hippocampal apoptosis, and learning deficits (Bass et al., 2004).

Whereas exogenous BDNF delivery to the cervical spinal cord is sufficient to elicit phrenic long-term facilitation (BakerHerman et al., 2004), and may exert beneficial effects on respiratory function after spinal injury, protein delivery to the CNS is often complicated by poor penetration, immune reactions, and complications attendant to receptor downregulation. Small, highly permeable molecules, such as A2a receptor agonists, that mimic BDNF effects on respiratory motor output could be a useful alternative to intermittent hypoxia and/or exogenous BDNF, because it is easy to deliver at relevant sites and improves respiratory function in animals with cervical spinal injuries.

Adenosinergic drugs are reported to improve respiratory function after cervical spinal injury (Bascom et al., 2005; Nantwi and Goshgarian, 2005). For example, systemic theophylline, a nonselective adenosine receptor antagonist, increases phrenic motor output below a $\mathrm{C} 2$ hemisection in rats via supraspinal mechanisms, but only when administered shortly after injury (Nantwi and Goshgarian, 2005). In fact, 8 weeks after C2 hemisection, theophylline effects are reversed, and theophylline now inhibits phrenic motor output (Nantwi and Goshgarian, 2005). Thus, after chronic C2 hemisection, theophylline may be detrimental to respiratory function. Our data suggest that adenosinergic agonists may be a more appropriate strategy in chronically injured patients.

Our observations that systemic A2a receptor activation stimulates ventilation with a magnitude and time course similar to phrenic motor facilitation after spinal A2a receptor activation supports the feasibility of this approach to achieve functional benefits in patients with multiple ventilatory control disorders (Mitchell, 2007). CGS 21680 has a short half-life $\left(T_{1 / 2}<15 \mathrm{~min}\right)$, and continued $\mathrm{A} 2 \mathrm{a}$ receptor occupancy is an unlikely contributor to ventilatory facilitation $60 \mathrm{~min}$ after injection. Any prolonged ventilatory effects after drug administration most likely arise from enduring effects such as protein synthesis-dependent transactivation of Trk receptors. Although we suggest that A2ainduced ventilatory facilitation after systemic CGS 21680 administration results largely from the same spinal mechanisms of A2ainduced phrenic motor facilitation, we cannot completely rule 
out actions at other sites, such as the carotid body chemoreceptor (Gozal, 1998; Vandier et al., 1999; Kobayashi et al., 2000; Bae et al., 2005). Although A2a-induced ventilatory facilitation appears modest, even small increments in respiratory function can significantly enhance quality of life and reduce morbidity in ventilatordependent patients, particularly if the functional gain tips the balance, allowing even partial ventilator independence.

\section{References}

Armanini MP, McMahon SB, Sutherland J, Shelton DL, Phillips HS (1995) Truncated and catalytic isoforms of trkB are co-expressed in neurons of rat and mouse CNS. Eur J Neurosci 7:1403-1409.

Arvanian VL, Bowers WJ, Anderson A, Horner PJ, Federoff HJ, Mendell LM (2006) Combined delivery of neurotrophin-3 and NMDA receptors 2D subunit strengthens synaptic transmission in contused and staggered double hemisected spinal cord of neonatal rat. Exp Neurol 197:347-352.

Bae H, Nantwi KD, Goshgarian HG (2005) Recovery of respiratory function following $\mathrm{C} 2$ hemi and carotid body denervation in adult rats: influence of peripheral adenosine receptors. Exp Neurol 191:94-103.

Baker-Herman TL, Fuller DD, Bavis RW, Zabka AG, Golder FJ, Doperalski NJ, Johnson RA, Watters JJ, Mitchell GS (2004) BDNF is necessary and sufficient for spinal respiratory plasticity following intermittent hypoxia. Nat Neurosci 7:48-55.

Bascom AT, Lattin CD, Aboussouan LS, Goshgarian HG (2005) Effect of acute aminophylline administration on diaphragm function in high cervical tetraplegia: a case report. Chest 127:658-661.

Bass JL, Corwin M, Gozal D, Moore C, Nishida H, Parker S, Schonwald A, Wilker RE, Stehle S, Kinane TB (2004) The effect of chronic or intermittent hypoxia on cognition in childhood: a review of the evidence. Pediatrics 114:805-816.

Bocchiaro CM, Feldman JL (2004) Synaptic activity-independent persistent plasticity in endogenously active mammalian motoneurons. Proc Natl Acad Sci USA 101:4292-4295.

Bolser DC, Lindsey BG, Shannon R (1988) Respiratory pattern changes produced by intercostal muscle/rib vibration. J Appl Physiol 64:2458-2462.

Bramham CR, Messaoudi E (2005) BDNF function in adult synaptic plasticity: the synaptic consolidation hypothesis. Prog Neurobiol 76:99-125.

Carter AR, Chen C, Schwartz PM, Segal RA (2002) Brain-derived neurotrophic factor modulates cerebellar plasticity and synaptic ultrastructure. J Neurosci 22:1316-1327.

Drorbaugh JE, Fenn WO (1955) A barometric method for measuring ventilation in newborn infants. Pediatrics 16:81-87.

Eldridge FL (1975) Relationship between respiratory nerve and muscle activity and muscle force output. J Appl Physiol 39:567-574.

Eldridge FL, Gill-Kumar P, Millhorn DE, Waldrop TG (1981) Spinal inhibition of phrenic motoneurones by stimulation of afferents from peripheral muscles. J Physiol (Lond) 311:67-79.

Eldridge FL, Millhorn DE, Waldrop T (1987) Spinal inhibition of phrenic motoneurones by stimulation of afferents from leg muscle in the cat: blockade by strychnine. J Physiol (Lond) 389:137-146.

Feldman JL, McCrimmon DR (2002) Neural control of breathing. In: Fundamental neuroscience, Ed 2 (Squire LR, ed), pp 967-990: Academic.

Feldman JL, Mitchell GS, Nattie EE (2003) Breathing: rhythmicity, plasticity, chemosensitivity. Annu Rev Neurosci 26:239-266.

Fuller DD, Johnson SM, Olson Jr EB, Mitchell GS (2003) Synaptic pathways to phrenic motoneurons are enhanced by chronic intermittent hypoxia after cervical spinal cord injury. J Neurosci 23:2993-3000.

Fuller DD, Golder FJ, Olson Jr EB, Mitchell GS (2006) Recovery of phrenic activity and ventilation after cervical spinal hemisection in rats. J Appl Physiol 100:800-806.

Golder FJ, Mitchell GS (2005) Spinal synaptic enhancement with acute intermittent hypoxia improves respiratory function after chronic cervical spinal cord injury. J Neurosci 25:2925-2932.

Golder FJ, Reier PJ, Davenport PW, Bolser DC (2001) Cervical spinal cord injury alters the pattern of breathing in anesthetized rats. J Appl Physiol 91:2451-2458.

Golder FJ, Fuller DD, Davenport PW, Johnson RD, Reier PJ, Bolser DC (2003) Respiratory motor recovery after unilateral spinal cord injury: eliminating crossed phrenic activity decreases tidal volume and increases contralateral respiratory motor output. J Neurosci 23:2494-2501.

Gozal D (1998) Potentiation of hypoxic ventilatory response by hyperoxia in the conscious rat: putative role of nitric oxide. J Appl Physiol 85:129-132.

Huang EJ, Reichardt LF (2003) Trk receptors: roles in neuronal signal transduction. Annu Rev Biochem 72:609-642.

Kobayashi S, Conforti L, Millhorn DE (2000) Gene expression and function of adenosine $\mathrm{A}(2 \mathrm{~A})$ receptor in the rat carotid body. Am J Physiol Lung Cell Mol Physiol 279:L273-L282.

Lee FS, Chao MV (2001) Activation of Trk neurotrophin receptors in the absence of neurotrophins. Proc Natl Acad Sci USA 98:3555-3560.

Lee FS, Rajagopal R, Chao MV (2002) Distinctive features of Trk neurotrophin receptor transactivation by $\mathrm{G}$ protein-coupled receptors. Cytokine Growth Factor Rev 13:11-17.

Mitchell GS (2007) Respiratory plasticity following intermittent hypoxia: a guide for novel therapeutic approaches to ventilatory control disorders. In: Genetic basis for respiratory control disorders (Gaultier C, ed). New York: Springer.

Mitchell GS, Johnson SM (2003) Neuroplasticity in respiratory motor control. J Appl Physiol 94:358-374.

Mitchell GS, Baker TL, Nanda SA, Fuller DD, Zabka AG, Hodgeman BA, Bavis RW, Mack KJ, Olson Jr EB (2001) Invited review: intermittent hypoxia and respiratory plasticity. J Appl Physiol 90:2466-2475.

Mutoh T, Hamano T, Tokuda A, Kuriyama M (2000) Unglycosylated Trk protein does not co-localize nor associate with ganglioside GM1 in stable clone of PC12 cells overexpressing Trk (PCtrk cells). Glycoconj J 17:233-237.

Nantwi KD, Goshgarian HG (2005) Adenosinergic mechanisms underlying recovery of diaphragm motor function following upper cervical spinal cord injury: potential therapeutic implications. Neurol Res 27:195-205.

Neverova NV, Saywell SA, Nashold LJ, Mitchell GS, Feldman JL (2007) Episodic stimulation of $\alpha 1$-adrenoreceptors induces protein kinase C-dependent persistent changes in motoneuronal excitability. J Neurosci 27:4435-4442.

Olson Jr EB, Bohne CJ, Dwinell MR, Podolsky A, Vidruk EH, Fuller DD, Powell FL, Mitchel GS (2001) Ventilatory long-term facilitation in unanesthetized rats. J Appl Physiol 91:709-716.

Rajagopal R, Chen ZY, Lee FS, Chao MV (2004) Transactivation of Trk neurotrophin receptors by G-protein-coupled receptor ligands occurs on intracellular membranes. J Neurosci 24:6650-6658.

Sajikumar S, Navakkode S, Frey JU (2005) Protein synthesis-dependent long-term functional plasticity: methods and techniques. Curr Opin Neurobiol 15:607-613.

Skup M, Dwornik A, Macias M, Sulejczak D, Wiater M, Czarkowska-Bauch J (2002) Long-term locomotor training up-regulates $\operatorname{TrkB}(\mathrm{FL})$ receptorlike proteins, brain-derived neurotrophic factor, and neurotrophin 4 with different topographies of expression in oligodendroglia and neurons in the spinal cord. Exp Neurol 176:289-307.

Vandier C, Conway AF, Landauer RC, Kumar P (1999) Presynaptic action of adenosine on a 4-aminopyridine-sensitive current in the rat carotid body. J Physiol (Lond) 515:419-429.

Watson FL, Porcionatto MA, Bhattacharyya A, Stiles CD, Segal RA (1999) TrkA glycosylation regulates receptor localization and activity. J Neurobiol 39:323-336.

White-Grindley E, Si K (2006) RISC-y memories. Cell 124:23-26.

Winslow C, Rozovsky J (2003) Effect of spinal cord injury on the respiratory system. Am J Phys Med Rehabil 82:803-814.

Yan Q, Elliott JL, Matheson C, Sun J, Zhang L, Mu X, Rex KL, Snider WD (1993) Influences of neurotrophins on mammalian motoneurons in vivo. J Neurobiol 24:1555-1577. 